Deng, Z. (2018 in press). Contemporary curriculum theorizing: Crisis and resolution. Journal of Curriculum Studies, 50(6), xxx-xxx

\title{
Contemporary Curriculum Theorising: Crisis and Resolution
}

\section{Zongyi Deng}

National Institute of Education, Nanyang Technological University

\begin{abstract}
Using the 'medical' framework (symptoms, diagnosis and prescription) in Schwab's (1970/2013) the Practical 1 article, I analyse the current state of contemporary curriculum theorising as a result of the re-conceptualist movement. I argue that curriculum theorising is in serious crisis due to the loss of the original subject of curriculum studies - practice and the inner work of schooling as a complex institution. Furthermore, I contend that the crisis has to do with the task of theorising being mistakenly viewed as the pursuit of 'complicated' curriculum understanding, together with an uncritical embrace of postmodernism and related discourses. Based on Schwab' the Practical and informed by the German Didaktik tradition, I propose a way forward to overcome the crisis and to revive curriculum theorising that matters in practice and in the world of schooling for the twenty-first century in terms of three propositions. First, curriculum studies is a distinct discipline/field centrally concerned with practice for the advancement of education. Second, practice and the inner work of schooling provide the essential starting point and subject matter for theorising. Third, curriculum theorising requires the use of theories in an eclectic, critical and creative manner.
\end{abstract}

Keywords: reconceptualision; curriculum theory; Didaktik; deliberation; Schwab; curriculum inquiry. 
[T] he field of curriculum is moribund. It is unable, by its present methods and principles, to continue its work and contribute significantly to the advancement of education. It requires new principles which will generate a new view of the character and variety of its problems. It requires new methods appropriate to the new budget of problems. (Schwab, 1970/2013, p. 591)

A year after the founding of the Journal of Curriculum Studies (JCS) in 1968, at the 1969 meeting of American Educational Research Association (AERA) Joseph Schwab made a diagnosis of the 'moribund' state of curriculum studies and called for the adoption of 'new principles' and 'new methods' in the field. (His AERA paper was first published in School Review in 1969, and a modified version of which was then published as a monograph in 1970 by the National Education Association. The 1970 version was republished in JCS, Vol 45, No. 5, 2013.) About ten years later, William Pinar published an article 'The reconceptualization of curriculum studies' in JCS in which he laid out the rationale and justification for the reconceptualist movement which had been underway since the early 1970s (Pinar, 1978). The movement, as seen by Pinar and his collaborators, was a response to Schwab's call for new principles and new methods in the field (see Pinar, 1975; Pinar et al., 1995).

As a result, a paradigm shift has occurred, in which curriculum development - the primary preoccupation of traditional curriculum studies - 'was replaced by a multi-discursive academic effort to understand curriculum: historically, politically, racially, autobiographically or biographically, aesthetically, theologically, institutionally and internationally, as well as in terms of gender, phenomenology, postmodernism, and poststructuralism' (Pinar, 2008, p. 493; also see Pinar et al., 1995). The term curriculum refers to a variety of experience. Associated with the movement is a distinctive form of curriculum writing, called curriculum theorising or 
contemporary curriculum theorising, that is marked by a radical broadening of the scope, and the theoretical and methodological perspectives of the curriculum field. The scope of curriculum theorising is extended to encompass culture, politics, ethnicity, gender, race, subjectivity, identity, agency, and so forth. Theoretical perspectives are drawn from not only traditional humanities and social sciences but also more recent philosophical discourses such as postmodernism, poststructuralism, deconstruction, feminism and so forth. Modes of inquiry include autobiographic, narrative, aesthetic, phenomenological, and hermeneutic inquires, in addition to conventional philosophical, historical, and sociological studies (Pinar et al., 1995).

The beginning of the twenty-first century saw the emergence of post-reconceptualist curriculum studies that has further widened the scope and theoretical perspectives of curriculum theorising. Post-reconceptualist curriculum studies deals with a dizzying array of eccentric and exotic topics: rural formations of queerness, intersubjective becoming, post-human condition, biomedical world, eugenic ideology, suicide policy, despair, technological flow, spiritualism, critical geography, hospitality, and ecological ways of knowing, among others. New theoretical perspectives include posthumanism, queer theory, critical animal studies, and so forth (Malewski, 2010). In the post-reconceptualised field curriculum theorists are to be in the spirit of 'let a thousand flowers bloom' and always committed to pushing theoretical and methodological boundaries.

It is all too obvious that curriculum practice (curriculum planning, curriculum development, curriculum enactment or teaching) and topics like curriculum contents or subject matters have disappeared from the expanding horizon of contemporary curriculum theorising. The 'inner work of schooling' as a complex institution (Westbury, 2008) - the core subject of the curriculum field-is no longer a basic concern for most contemporary curriculum theorists. The 
reconceptualist movement, together with its subsequent post-modern/poststructural turn, has transformed the curriculum field into a kind of postmodern cultural studies that encompasses literally any topic pertaining to politics, culture, society, environment, technology, and human existence.

As a contribution to the $50^{\text {th }}$ anniversary issue of $J C S$, this essay provides a critical analysis of the current state of contemporary curriculum theorising and, in so doing, advances a way forward to overcome the crisis and to revive curriculum theorising for the twenty-first century. It also serves as an introductory essay for the JCS virtual issue titled 'Contemporary curriculum theorising'. Using Schwab (1970/2013) and Pinar (1978) as points of departure, I will conduct the analysis and develop my arguments by way of a selection of articles from the pages of $J C S$, with reference to a larger body of literature in the field. The selected articles include, notably, Apple (1990), Connelly (2013), Doll (1989), Graham (1992), Popkewitz (2009), Westbury (2013), and Wraga \& Hlebowitsh (2003), in addition to Schwab (1970/2013) and Pinar (1978). In this essay curriculum theorising refers to 'any act of thought about curriculum matters, any phases in construction of a curriculum theory and/or any dimension of analysis of curriculum concepts, practice or principles' (Schubert, Willis, \& Short, 1984, p. 70) a notion that is consistent with the reconceptualist movement.

I start with providing a brief review of the reconceptualist movement and examining four strands of curriculum theorising associated with the movement. This is followed by a revisiting of Schwab's (1970/2013) article and applying the analytic framework in that article to detect and diagnose the crisis in contemporary curriculum theorising. Afterwards, I discuss how the crisis can be overcome and how curriculum theorising can be re-conceived in a way that matters in 
practice and in the world of schooling. I conclude by addressing the challenges for curriculum theorists to revive curriculum theorising for the twenty-first century.

\section{The reconceptualist movement}

The reconceptualisation of curriculum studies is an intellectual movement against the traditional curriculum field - a field that is primarily driven by the concern for curriculum development in service of the existing school system. For reconceptualists, the traditional field is well 'epitomized' in Tyler's (1949) Basic Principles of Curriculum and Instruction, that is, the Tyler Rationale, the raison d'être of American curriculum studies (Pinar, 1978). In the text the essential themes of American curriculum studies are readily found. The primary aim is to provide 'service to practitioners' in the form of consultation and guidance. Curriculum practice (curriculum development, implementation, evaluation) is seen as a technological and rationalistic undertaking. It is technological in that practice is characterised by a series of techniques for goal/objective formation, content selection, organisation, assessment, and evaluation. It is rationalistic in that practice entails the employment of models and frameworks based on scientific research and analysis (Westbury, 2000). On this account, curriculum theorising is directed toward the development of models and frameworks that could guide curriculum practice based on school experience and scientific research. As such, curriculum theorising has to concern itself with the real-world practice of schools and classrooms.

The reconceptualist movement is predicated on a denunciation and repudiation of the traditional field. Curriculum studies is criticised for its ahistorical and atheoretical posture, and its technological and rationalistic characters. The Tyler Rationale is attacked for its presumed connection with Bobbitt's efficiency/production model, its espousal of behaviouristic outcomes 
and controlling methods of instruction, and its neglect of the complexities of the moral and aesthetic dimensions of school and classroom lives (Kliebard, 1970, 1986; Pinar, 1978; Pinar et al., 1995). Traditional curriculum theory, too, has been questioned for its unquestioning acceptance of institutional priorities and its neglect of broad social and political issues that have an inexorable bearing on the school curriculum (see Apple, 2004; Kliebard, 1992; Pinar et al., 1995).

However, curriculum reconceptualists have been questioned for their mis-criticisms of the Tyler Rationale (Hlebowitsh, 1992, 1995; Wraga \& Hlebowitsh, 2003). 'Many of these extended criticisms of the Rationale', Hlebowitsh (1995) observed, 'went against the historical record and fundamentally failed to understand that the Tyler Rationale was more than one man's idea on curriculum development' (pp. 89-90). A more adequate, responsible reading of the Tyler Rationale, Westbury (2005) argued, needs to take account of the transformation of American secondary education during the 1920s and 1930s, the Eight Year Study (1930-1942), and the intellectual milieu in the Department of Education at the University of Chicago where Tyler worked.

Nevertheless, in spite of these criticisms, curriculum reconceptualists have succeeded in launching a paradigm shift in the field. Moving away from the preoccupation with curriculum practice, contemporary curriculum theorists see 'understanding curriculum' - i.e. the interdisciplinary study of a varieties of experience -as the primary purpose of curriculum studies. Contemporary curriculum theorists are to, as mentioned before, engage in 'multidiscursive academic effort to understand curriculum: historically, politically, racially, autobiographically or biographically, aesthetically, theologically, institutionally and internationally, as well as in terms of gender, phenomenology, postmodernism, and poststructuralism' (Pinar, 2008, p. 493). 
Correspondingly, the contemporary field is seen as consisting of historical, political, racial, gendered, phenomenological, autobiographical, aesthetic, theological, and international texts (Pinar, 2004; Pinar et al., 1995). ${ }^{1}$ Since the mid-1990s re-conceptualists have overtaken the field, declaring that 'curriculum development is dead' and that 'curriculum understanding is what is needed' (Pinar et al., 1995). The contemporary field 'has separated from the schools, and was traveling on its own, rather different, path' (Pinar et al., 1995, p. 238)

The turn of the century saw three main developments associated with the reconceptualist movement. First, a Pinarian project of the internationalisation of curriculum studies has been initiated, with an intent to create a worldwide 'complicated conversation' through ongoing dialogues and interactions between and among curriculum scholars across different countries and cultures (see Pinar, 2003, 2008; Trueit et al., 2003). In North America, the 'canon project' has been established to strengthen the 'disciplinarity' of curriculum studies as a 'complicated conversation', through providing synoptic expositions of the main ideas, texts, and scholars in the historical formation of curriculum studies (see Schubert, 2009). Furthermore, as noted earlier, there has been a movement toward a post-reconceptualisation of curriculum studies 'using interand intragenerational conversations to un[map] the next moments in the field' (Malewski, 2010, p. xi).

\section{Contemporary curriculum theorising}

In accord with the reconceptualist movement, contemporary curriculum theorising is no longer directed toward developing frameworks for curriculum development based on the empirical

\footnotetext{
${ }^{1}$ Associated with the traditional field, the 'institutional text' has been least discussed, if not ignored completely (see Pinar, 2008).
} 
reality of schooling. It is geared toward developing a heightened, sophisticated understanding or interpretation of 'educational experiences' informed by wide ranging theoretical sources such as Marxism or neo-Marxism, post-modernism, post-structuralism, post-colonialism, and feminism. In what follows I examine four strands of theorising associated with curriculum as (1) autobiographic text, (2) political text, (3) poststructuralist text, and (4) postmodern text.

Autobiographic curriculum theorising, first developed by Pinar and Grumet, foregrounds the experience of an individual, with a focus on issues of subjectivity, identity, agency, transformation, and so forth. Seeing the curriculum as the running of the course rather than a course of study, Pinar and Grumet developed an autobiographic theory of curriculum with the method of currere (see Graham, 1992). By way of currere, students and teachers analyse and reflect on their personal experiences and, in so doing, 'sketch the relations among school knowledge, life history, and intellectual development in ways that might function selftransformatively' (Pinar et al., 1995, p. 515). This approach to theorising is said to be grounded in the tradition of existentialism and draw on perspectives and tools from phenomenology, hermeneutics, critical theory, aesthetic inquiry, autobiographical inquiry, theological theory, gender studies, and racial theory (Grumet, 1976a, 1976b; Pinar et al., 1995). The method of currere has also been applied to feminist, ethnic, and cross-cultural curriculum theorising (Pinar, 2008).

Political curriculum theorising foregrounds the complex interplay between schooling, society, and culture. Grounded in Marxism or neo-Marxism, critical curriculum theorists develop theoretical propositions concerning the role of schools in general, and the curriculum (overt or hidden) in particular, in reproducing social inequalities within existing social order (e.g., Apple, 
2004; McLaren, 2015). ${ }^{2}$ In 'The politics of official knowledge in the United States', Apple (1990) postulated that 'The form schooling took, the curriculum that was instituted, the way teaching went on, how and by whom it was controlled' are outcomes of 'concrete struggles among different groups with different social and cultural visions, and of course different resources and power' (p. 377). Therefore, the traditional curriculum question - 'What knowledge is of most worth?' - is an inherently ideological and political question inextricably connected with issues of class, race, gender, and power relation. Curriculum theorists need to ask a more important and more fundamental question - 'Whose knowledge is of most worth?'.

Other political curriculum theorists foreground the agency of teachers and students and, in so doing, pustulate that teachers could engender transformative change in schools (e.g., Carlson, 1987, Giroux, 1988; Giroux \& McLaren, 1989). Over the last two decades, the scope of political curriculum theorising has been expanded to include cultural and ecological studies that provide 'strong critiques of those cultural assumptions embedded in schooling that prevent policies supporting sustainability' (Pinar, 2008, p. 494).

In the third strand curriculum theorists employ poststructural theories to deconstruct conventional curriculum concepts and models. This is evident in the article 'Curriculum study, curriculum history, and curriculum theory: the reason of reason' by Thomas Popkewitz. Based upon Foucault's concept of governmentality and Derrida's idea of deconstruction, Popkewitz (2009) articulated a set of interrelated analytic categories - including 'systems of reason', 'rules and standards', and 'cultural theses' - that serves to problematize or deconstruct extant curriculum concepts. With this set of categories, he explored political issues surrounding the

\footnotetext{
${ }^{2}$ While their scholarships have contributed to reconceptualising the curriculum field, critical curriculum scholars tend not see themselves as 'curriculum reconceptualists'. As Pinar et al. (1995) observed, Michael Apple would become one of the major figures in the movement to reconceptualise the field, although he disavowed any affiliation with the movement (p. 226).
} 
principle of inclusion/exclusion, school subjects, and pedagogical knowledge reform. Through 'historicising' the 'ways of reasoning' that are behind these educational concepts, he showed how these concepts function to regulate, order, and control what the individual should become, and how he or she should live. On this account, poststructural curriculum theorising entails an abandonment of conventional curriculum logic and an entry into a 'poststructuralist space' wherein conventional curriculum concepts and models are deconstructed (Pinar et al., 1995).

The fourth strand, postmodernist curriculum theorising, involves extrapolating theoretical implications of post-modernism and related discourses for curriculum and curriculum development. In ‘Foundations for a post-modern curriculum', William Doll developed a vision of post-modern curriculum based on post-modernism and related discourses such as complexity theory and systems theory. The curriculum was envisioned as 'a multifaceted matrix to be explored' and being planned through 'a two-tier or hierarchal process', in which 'the teacher and the students are seen in a sharing relationship' (Doll, 1989, pp. 251-252). This vision of curriculum is further developed and articulated in his book A post-modern perspective on curriculum (1993). Other examples of postmodernist curriculum theorising include Slattery (1995) and De Alba (2000), among others.

The above survey of four strands of contemporary curriculum theorising shows that curriculum theorising takes the forms of constructing theoretical accounts of individual experiences, developing theoretical expositions concerning the political nature of the curriculum, deconstructing traditional curriculum concepts and models, and extrapolating curriculum implications from post-modern theory. Since contemporary curriculum theorising is seen as a response to the call of Schwab, does it contribute to meliorating the moribund state of the field 
seen in the 1960s? Or, does the field now become more moribund? To address these two questions, I briefly revisit Schwab's the Practical 1 article.

\section{Revisiting Schwab's the Practical 1 article}

Schwab's the Practical 1 article is the first in the 'practical' series (Schwab, 1970/2013, 1971, 1973, 1983) - in which he made a case for a fundamental rethinking of the curriculum field and advocated the practical and the deliberative methods for tackling its moribund state. His remarks in the Practical 1 article 'touched on some deep problematic of the field that needed to be addressed' (Reid, 2001, p. 30).

As with the Tyler Rationale, Schwab's conception of the practical has been misread and superficially understood by many contemporary curriculum scholars. Schwab was blamed for calling for 'a moratorium on theoretical speculation', for a devotion of 'our attention to dealing with more practical affairs', and for immersing 'ourselves in the most satisfying but short-sighted tasks of solving immediate problems' (Staratt, 1974, as cited in Pinar et al., 1995, p. 220). He was accused of focusing 'much of his career on scientific principles' (Malewski, 2010, p. 2). Even eminent educational philosopher Phillip Jackson, Schwab's colleague at the University of Chicago, has misinterpreted the Practical 1 article. Lumping Schwab and Tyler together, Jackson (1992) saw Schwab as an exponent of the 'dominant perspective' and blamed him for advocating a 'problem centred approach' to curriculum development which focuses on 'the concrete and the immediate'.

Written in a dense, arcane, and difficult style, the Practical 1 article is found to be challenging even to native English speakers. It therefore demands a careful close reading. In addition, the article, together with the other three in the 'practical' series, was written for the 
occasion of addressing 'how the curriculum field should/might think anew about its traditional work of setting out platforms for and methods of curriculum-making in American public schools' (Westbury, 2013, p. 643). When writing the article Schwab draw on the Aristotelian tradition at the University of Chicago and his experience as a core figure in the development of the reformed liberal arts curriculum at the University of Chicago. ${ }^{3}$ Therefore, the article needs to be read in view of that occasion, the Chicago's Aristotelian tradition, and the curriculum reform project Schwab participated in.

In 'Reading Schwab's the "Practical" as an invitation to a curriculum enquiry', Westbury (2013) provides a much-needed exposition of the 'practical' depicted in the Practical 1 paper. $\mathrm{He}$ argued that there are two 'practicals' to be found in the paper:

- Practical 1.1 - A comprehensive outline of the form of the field of curriculum as a theoretic and practical endeavour.

- Practical 1.2 - An outline of a deliberation/phronesis-centred 'practical...(p. 624) Practical 1.2 has received tremendous attention in the educational research community, with a significant body of literature devoted to exploring the implications for curriculum deliberation, school-based curriculum development, teachers' personal practical knowledge, and teachers as researchers, among others. However, Practical 1.1 'has been the least discussed' and yet 'has the most exciting and far-reaching implications for educational and curriculum theory and research' (p. 624).

To understand Practical 1.1 properly, one needs to be aware of his earlier essay 'What do scientists do?' in which, based on approximately 4000 science papers, Schwab (1960) inquired

\footnotetext{
${ }^{3}$ Schwab was mainly responsible for the redesign of the natural sciences curriculum and played a major role in developing the capstone course, 'Observation, Interpretation, Integration'(OII) (see Levine, 2006; Westbury \& Wilkof, 1978).
} 
into the patterns of scientific inquiry and the debates surrounding those patterns. In addition, one also need to be cognizant of College Curriculum and Student Protest in which Schwab (1969) employed a kind of medical framework - symptoms, diagnosis, and prescription - to detect and analyse the issues and problems inherent the student protest movement in the 1960s. In so doing, he developed a way of tackling those issues and problems through a restatement of his commitment and belief about the power of liberal education.

It is, therefore, useful to ask 'what Schwab was doing' in the earlier part of the article (Connelly, 2013). Invoking the medical framework, Schwab detected the symptoms of crisis in the curriculum field in the 1960s, provided a diagnosis of the root cause of the crisis, and offered a prescription that can overcome the crisis.

- Symptoms: 'The field of curriculum is moribund.' The symptoms of the moribund state are 'six flights'.

- Diagnosis: The field of curriculum is experiencing a crisis of principle. '[It] is unable, by its present methods and principles, to continue its work and contribute significantly to the advancement of education'.

- Prescription: The field of curriculum 'requires new principles which will generate a new view of the character and variety of its problems. It requires new methods appropriate to the new budget of problems.' (Schwab, 2013, p. 591)

In other words, what Schwab was doing is to develop three basic, interrelated theses: (1) that the curriculum field is in crisis; (2) that the crisis is a paradigmic one -'a crisis of principle'; and (3) that the resolution to the crisis calls for a new paradigm characterized by 'new principles' and 'new methods' (see Connelly, 2013). 


\section{The crisis in contemporary curriculum theorising}

I now employ Schwab's (1970/2013) medical framework to detect and diagnose the crisis of the contemporary curriculum theorising. The six flights that symptomized the moribund state of the field in the 1960s were:

1. Flight of the field - a 'translocation' of curriculum problems and solutions from curriculum specialists to psychologists, scientists, and mathematicians, as evident in the American curriculum reform movement in the 1960s.

2. Flight upward - a flight 'from discourse about the subject of the field to discourse about the discourse of the field', "from theory to meta-theory, and from metatheory to metametatheory' (p. 604).

3. Flight downward - a return to "the subject matter in a state of innocence, shorn not only of current principles but of all principles' (p. 604).

4. Flight to the sideline - a retreat of curriculum specialists to 'the role of observer, commentator, historian, and critic of contribution of others to the field' (p. 604).

5. Flight to perseveration - 'a repetition of old and familiar knowledge in new language' (p. 604).

6. Flight to hot, caustic debates - 'rise in frequency and intensity of the eristic, contentious, ad hominem debates' (p. 604).

Connelly (2013), Deng (2013), and Wraga and Hlebowitsh (2003) have detected the contemporary curriculum field by means of these six flights. It is concluded that the symptoms 'are alive and well, taking on new forms' (Deng, 2013, p. 583) and 'become more obvious over time to an observer of curriculum studies than they were when Schwab wrote' (Connelly, 2013, 
p. 626). In other words, reconceptualists have responded to the crisis in the 1960 s, but in a wrong way - which has also become increasingly obvious over time (see Westbury, 2008).

First, today there is a 'translocation' of the task of curriculum making (curriculum policy making, curriculum planning, and curriculum development) from curriculum scholars to assessment specialists, learning scientists, and educational technologists who are tasked with developing academic standards, competency frameworks, and high-stakes tests (Deng, 2013). Contemporary curriculum scholars have been further marginalized and ignored by the US government and policy makers (see Connelly, 2013). And, research on curriculum practice has been increasingly conducted by researchers in other areas such as educational policy, educational leadership, and teacher education.

With respect to the second flight, most contemporary curriculum theorists have been 'manifesting a greater commitment to talk about rather than to engage with curriculum endeavours' (Wraga \& Hlebowitsh, 2003, p. 427). Since the mid-1980s, there have been an upward flight to 'exotic' and 'fashionable' discourses such as postmodernism, poststructuralism, postcolonialism, and so forth (Deng, 2013).

The third flight, a flight downward, is marked by a complete repudiation of all traditional curriculum theories and practices. 'By dismissing principles and practices that emerged from the historic US field,' Wraga and Hlebowitsh (2003) observed, 'reconceptualists are able to return to curriculum matters innocent of earlier work', leading to 'a reinvention of ideas and practices' ( $\mathrm{p}$. 427).

As far a flight to the sidelines, most contemporary curriculum theorists have taken on the role of commentators and critical outsiders, increasingly distancing themselves from the real world and practice of schools and classrooms (Deng, 2013). '[A]n intellectual and cultural 
distance from' curriculum practitioners, Pinar (1978) believed, is necessary 'in order to develop a comprehensive critique and theoretical programme that will be of any meaningful assistance now or later' (p. 6). It is also claimed that 'Theory must stay out of bed with current reform in order to remain free to theorise modes of knowing and knowledge linked with neither the factory nor corporate model' (Pinar, 1992, p. 234).

A flight to perseveration, Connelly (2010) observed, takes the form of 'endlessly interpreting newly discovered foundational theory [usually European]'. Later, he further noticed that 'People discover a philosopher, often European but now perhaps Asian, find a unique quote or idea of interest and begin to write curriculum theory papers and books' (Connelly, 2013, p. $631)$.

The last flight, a flight to hot, caustic debates, is indicated in the setting up of straw men (e.g., via distorted interpretations of the Tyler Rationale), the regular deployments of ad hominem, and the regular attempts to silence opposing voices. This is evident in the 1999 exchange between Pinar and Wraga and subsequent commentaries provided by curriculum reconceptualists (for detail, see Wraga \& Hlebowitsh, 2003). This is also indicated in the intense fractionalisation of the field into various mutually exclusive groups or camps, leading to what is called 'discursive balkanisation' that 'threatens to stifle that which it is challenged to maintain: open and interpretive dialogue' (Christou \& Deluca, 2013, p. 13).

Therefore, sufficient evidence exists to support that the curriculum field - characterized by contemporary curriculum theorising - becomes more moribund than it was when Schwab wrote the Practical 1 article. The above manifestations of the six flights, after all, indicate a radical flight or departure from the subject of curriculum theory that is defined by practice and the inner work of schooling as a complex institution (Westbury, 2008). At the heart of the subject 
are curriculum subject matters and preoccupations - curriculum development, curriculum

evaluation, curriculum implementation, and curriculum policy development and analysis (Connelly $\& \mathrm{Xu}, 2010)$. However, curriculum subject matters and preoccupations, as indicated earlier, have literally entirely disappeared from contemporary curriculum theory and discourse. ${ }^{4}$ Because of the flight from practice and the institution of schooling, much contemporary curriculum theorising becomes, in the words of Hlebowitsh (1992), 'like a free-floating cloud, covering a vast territory, always airy and never touching ground' (p. 94).

How would we explore and think about the crisis in theorizing in the contemporary curriculum field? What would be the root cause and fundamental problems? To address these two questions, I now turn to unpack Schwab's diagnosis of the crisis in the 1960s and then apply his idea to diagnose the crisis in contemporary curriculum theorising.

\section{A diagnosis of the crisis in contemporary curriculum theorising}

As indicated above, in the Practical 1 article Schwab (1970/2013) provided a diagnosis of the crisis in the curriculum field and a prescription for overcoming the crisis. The diagnosis and prescription were developed based on the distinction between the theoretic and the practical - in terms of outcomes, subject matter, problem source, and methods - shown in Table 1.

\footnotetext{
${ }^{4}$ Curriculum subject matters and preoccupations are largely excluded from the topics of presentation in the Curriculum Studies Division (Division B) at the annual meetings of the American Educational Research Association (AERA). Consider the division's call for its most recent annual meeting. The proposal categories are: Pasts and Emerging Futurities (The Theorizing Moments of Curriculum); Methodologies, Cosmologies, and Philosophies (The Shaping of Curriculum); Policies and Politics (The Webbings of Curriculum); Places and Praxis (The "Where-Abouts" of Curriculum); and De/Colonization and Desire (The Wanting of Curriculum). Two years ago, a good quality academic paper (written by the author) addressing fundamental curriculum questions about knowledge and content got desk-rejection from Curriculum Inquiry, a recent postmodernist-turned journal, on the grounds that the paper did not engage with posthumanism, postcolonialism, and feminism.
} 
Table 1. The distinction between the theoretic and the practical (adopted from Westbury [2013], with modifications).

\begin{tabular}{|c|c|c|}
\hline & $\begin{array}{l}\text { Theoretic (mathematics, } \\
\text { physics, metaphysics) }\end{array}$ & Practical (politics, ethics) \\
\hline $\begin{array}{l}\text { End/Outcome } \\
\text { (Final cause) }\end{array}$ & $\begin{array}{l}\text { 'General or universal } \\
\text { statements } \\
\text { which are supposed to be } \\
\text { true, } \\
\text { warranted, confidence- } \\
\text { inspiring' }\end{array}$ & $\begin{array}{l}\text { 'A decision, a selection and guide } \\
\text { to possible action' }\end{array}$ \\
\hline $\begin{array}{l}\text { Problem- source } \\
\text { (Formal cause) }\end{array}$ & $\begin{array}{l}\text { 'Theoretic problems are } \\
\text { states of } \\
\text { mind' }\end{array}$ & $\begin{array}{l}\text { 'Practical problems ... arise from } \\
\text { states of affairs in relation to } \\
\text { ourselves' }\end{array}$ \\
\hline $\begin{array}{l}\text { Subject matter } \\
\text { (Material cause) }\end{array}$ & $\begin{array}{l}\text { Concepts and abstract } \\
\text { representations: universal, } \\
\text { constant, impervious to } \\
\text { changing circumstance }\end{array}$ & $\begin{array}{l}\text { Specific and concrete cases: } \\
\text { susceptible to circumstance, liable to } \\
\text { unexpected changes }\end{array}$ \\
\hline $\begin{array}{l}\text { Methods } \\
\text { (efficient cause) }\end{array}$ & $\begin{array}{l}\text { 'The principle of a theoretic } \\
\text { enquiry determines the } \\
\text { general }\end{array}$ & $\begin{array}{l}\text { 'The problem slowly emerges, } \\
\text { then, as we search for data, and } \\
\text { conversely, the search for data is }\end{array}$ \\
\hline
\end{tabular}




\begin{tabular}{|l|l|l|}
\hline $\begin{array}{l}\text { shape of its problem, the } \\
\text { kind of } \\
\text { data to seek, and how to } \\
\text { interpret } \\
\text { these data to a } \\
\text { conclusion .... }\end{array}$ & problem’ \\
&
\end{tabular}

It is important to note that in making the theoretic-practical distinction, Schwab invoked the Aristotelian distinction between theoretic disciplines (mathematics, physics, metaphysics) and practical disciplines (politics, ethics). In addition, he drew on the Aristotelian notion of four causes - the final, the material, the formal, and the efficient - paralleling outcomes, subject matter, problem source, and methods (Westbury, 2013).

For Schwab, to invoke the theoretic-practical distinction is to contend that the curriculum field is not a theoretic discipline like physics aiming at generating general theories and principles for the sake of theoretical understanding. It is, instead, a practical discipline like politics centrally concerned with doing and decision-making for the ultimate purpose of advancing practice. The moribundity of the field in the 1960s, therefore, lies in it being mis-positioned as a theoretical field - wherein curriculum specialists were preoccupied with constructing theories of curriculum and instruction particularly based on behavioural sciences. The field 'has been inveterately theoretic and its theoretic bent has let it down' (Schwab, 1970/2013, p. 606).

This diagnosis, together with the theoretic-practical distinction that underpins the diagnosis, is highly instructive for understanding the root cause of the crisis in curriculum 
theorising within the re-conceptualized field. The task of curriculum theorising has been framed within the framework of the theoretic, that is, in terms of pursuing theory for the sake of 'complicated' curriculum understanding - rather than in terms of informing doing and decisionmaking for advancing curriculum practice. Moreover, the 'subject matters' for theorising are derived from theoretical sources - existentialism, Marxism, post-modernism and related discourses - which are of anti-establishment in essence (see Hicks, 2004). The embrace of such theoretical sources can be traced back to the anti-Vietnam protests, Civil Rights, and sociocultural movements in the 1960s and 1970s. Westbury explained:

In the U.S. many of these younger people were heavily involved in the anti-Vietnam protest movements of the 1960s with its links to both the radical left as well as the last era of the civil rights movement. One outcome was the reflection of the left-leaning antiVietnam and Civil Rights movements in people like Mike Apple, Henry Giroux, and later Bill Ayers in Chicago_- but also, I think, the early Bill Pinar. And then later, in the 1970s, curriculum theory was taken over by the socio-cultural movements of the 1970s, feminism, race, later LGBT, etc.. Accompanying all this was a movement towards seeing curriculum theory as cultural studies, led in the first instance by people like Madeleine Grumet, Bill Pinar, Tom Popkewitz, and Henry Giroux. (Ruzgar, 2018 [this issue], pp. $\mathrm{xxx}-\mathrm{Xxx})$

In this connection, contemporary curriculum theorising, Westbury (2007) argued, has made a 'wrong turn' - away from practice and the actual world of schooling and toward theoretical sources in contemporary humanities and social sciences. It has lost sight of the mission of the improvement of schooling as an end-in-view (Westbury, 2013). 
Certain issues are immediately obvious - concerning the use of Marxism or neo-Marxism and existentialism as theoretical sources for curriculum theorising. According to Schwab (1970/2013), all theory is incomplete and partial; it highlights certain facets of phenomena but thrusts other facets into the background. All theory, too, entails a 'special bias [partiality of view] imposed on the selection and interpretation of facts' (p. 660). Therefore, a curriculum theory built on only one theoretical source is 'incomplete' and 'doctrinaire'. Whereas Marxism or NeoMarxism sheds light on the reproduction of hierarchical social structures in terms of power and class struggle, it is silent on social and economic development, cultural continuity, and cultural innovation. It also fails to recognize the fact that hierarchical structures in society can be predicated on competence, qualification, and mutual consent - rather than 'tyrannical power' and class struggle (Peterson, 2017a). As a result, Marxist or neo-Marist critical curriculum theorising brings to light the role played by the curriculum in perpetuating and reproducing inequalities within extant social order, and challenges us to ask important questions about powers and politics lurking behind the curriculum process. It, however, has nothing to say about how the curriculum can contribute the academic, social, cultural and personal purposes or functions of schooling as a public institution (see Goodlad, 1984) Likewise, whereas existentialism foregrounds the importance of an individual's finding his or her identity and search for meaning of life, it says very little about how the individual can become a productive, competent, and responsible citizen in a democratic society. As a result, autobiographical curriculum theorising informed by existentialism sheds light on matters of individual agency, self-transformation, and emancipation. However, it contributes very little to our understanding of how the curriculum prepares students for citizenry in view of social, economic and cultural expectations and demands. 


\section{Further issues - the postmodern turn}

There are other issues having to do with the embrace of postmodern doctrines as axiomatic principles in contemporary curriculum theory and theorising. Post-modernism, developed by French intellectuals in the 1950s and 1960s, can be seen as a philosophical transformation of Marxism. ${ }^{5}$ It is a sophisticated philosophical movement against modernism and Western civilization, and its theoretical expansions include poststructuralism, postcolonialism, and posthumanism, among others. A detailed review of post-modernism and its further development is beyond the scope of this paper. Suffice it to outline four basic doctrines that can account for many of the tendencies inherent in contemporary curriculum theorising and, in part, explain the collapse of curriculum studies in North America.

1. Postmodernism abandons the notions of grand narrative, truth, and human reason. All knowledge and truth are socially constructed. It is impossible to use objective reason to gain objective knowledge and truth that are unaffected by subjective beliefs and opinions. Postmodernists celebrate the emergence of 'little narratives' - none of which has a claim to universal truth status.

2. All claims to knowledge, truth and meta-narrative are constructed to serve those in power. Therefore, what is taken to be knowledge or truth is the dominant world view that people have been provided with.

\footnotetext{
${ }^{5}$ The key figures of the postmodern vanguard, Michel Foucault, Jacques Derrida, Jean-François Lyotard, and Richard Rorty, were all Marxists during 1960s and 1970s. As Hicks (2004) observed, 'postmodernism is a symptom of the far Left's crisis of faith. Postmodernism is a result of using skeptical epistemology to justify the personal leap of faith necessary to continue believing in socialism' (p. 181)
} 
3. All existing hierarchical social structures are predicated on powers that are unevenly distributed. Therefore, the world is a battle ground of different power groups within a power hierarchy - each group generates its own internal narratives, including rules for what constitutes evidence that support or oppose the structure of that hierarchy.

4. People are viewed in terms of group identities -- race/ethnicity, class, gender, sexual orientation, nationality, religious and political affiliations, and so forth. Postmodernists tend to be on the side of the weaker and historically-oppressed groups. Because the dominant hierarchy tends to exclude these groups, it is in the best interest of these excluded groups to 'invert' the dominant hierarchy (Hicks, 2004; Peterson, 2017a).

The rejection of grand narrative, truth, and human reason leads naturally to embracing plurality and diversity. As a result, the curriculum field becomes increasingly fragmented and diversified, with the establishment of diverse affiliations and special interest groups specializing in wide-ranging topics like, politics, diversity, race, gender, LGBT, etc. The embrace of the second and the third doctrines means that curriculum making is not a rational, deliberative decision making process, but a political process in which dominant groups, through the exercise of powers, pursue their interest and agenda at the expense of less powerful groups. The prime responsibility of curriculum theorists, then, is to expose and unravel the interest, ideology, and agenda of those in powers and to unmask the political mechanism through which dominant groups exercise power and control over weaker groups. In this connection, 'what knowledge is of most worth?' and 'what constitutes curriculum content or subject matter?' are no longer important curriculum questions - but 'whose knowledge is of most worth?' and 'whose interest or agenda curriculum content or subject matter does serves?'. The embrace of the fourth doctrine 
entails a commitment to a vision of a multicultural curriculum that affirms and validates 'every voice in the school community' (Slattery, 1995) and pursues social justice for the weak and the downtrodden.

In short, the acceptance of these four postmodern doctrines entails a further rejection of the primary concern for curriculum development - together with the fundamental knowledge/subject matter questions - in the traditional field. Furthermore, to embrace postmodernism is to repudiate all educational and curricular traditions associated with modernism and Western civilization. Postmodern curriculum theory and theorising, in the words of Pinar and his collaborators, 'challenge and subvert not only the central themes, organizing metaphors, and discursive strategies constituting Western thought and informing the Enlightenment project, but all that is modernism itself' (Pinar et al., 1995, p. 405). Therefore, there is a strong connection between the postmodern turn and the decline of the traditional field of curriculum studies.

However, postmodernism has been severely challenged by a host of scholars (e.g., Hicks, 2004; Sokal \& Bricmont, 1998; Peterson, 2017a \& b). ${ }^{6}$ Given that the curriculum reconceptualist movement, and the postmodernist turn associated with the movement, are highly problematic and fundamentally questionable, is there an alternative way of reconceptualising curriculum studies that can avoid the problems and issues inherent in reconceptualist movement? How would the curriculum field be re-conceived in a way that can overcome the issues and limitations inherent in the traditional curriculum theory as typified in the Tyler Rationale, while

\footnotetext{
${ }^{6}$ For instance, with respect to Doctrine 2, claims to knowledge, truth and metanarrative are not only about tyrannical powers. They are necessarily bound up with the use of 'evidence, method, logic, or even the necessity for coherence' and the reality which is 'outside the text' (Peterson, 2017b, p. 314). As for Doctrine 3, in a democratic, well-functioning society, competence (ability or skill) - not (tyrannical) power - is a 'prime determiner' of the social status of an individual. Furthermore, 'the most valid personality trait predictors of long-term success in Western countries are intelligence... and conscientiousness (p. 313).
} 
maintaining its central concern with curriculum practice for the advancement of education in our times? How would theorising be characterized in such a reconceived 'practical' field? I now turn to Schwab's resolution - the prescription.

\section{Toward Resolution}

As noted earlier, for Schwab (1970/2013), the resolution to the crisis in the curriculum field in the 1960s calls for 'new principles' and 'new methods' in terms of three modes of operation: 'only if curriculum energies are in large part diverted from theoretic pursuits...to three other modes of operation... the practical, the quasi-practical and the eclectic' (p. 592). I now venture to articulate a way forward for addressing the crisis in contemporary curriculum theorising and for advancing curriculum theorising in the $21^{\text {st }}$ century in view of these three modes. My articulation is also informed by the German Didaktik tradition - within the European history of educational thinking - introduced to the English-speaking world by JCS editors, Stefan Hopmann and Ian Westbury, through the project of Curriculum and/or Didaktik dialogue (1994 2000) (see Hopmann \& Riquarts, 1995). Didaktik (European equivalent of curriculum studies) is highly compatible with Schwab's 'practical' thinking (see Künzli, 2013). ${ }^{7}$ Three propositions are made - concerning (1) the nature of curriculum as a distinct 'practical' field of study, (2) the necessity of practice and the inner work of schooling as the starting point and subject for curriculum theorising, and (3) eclecticism in theory development.

\footnotetext{
${ }^{7}$ As Westbury explained, 'it became clear that Didaktik was, in a sense, "practical." It came out the same Aristotelian and hermeneutic traditions as McKeon and Schwab, although Didaktik as a development of rhetoric has its own tradition' (Ruzgar, 2018 [this issue], pp. xxx).
} 
Curriculum studies, first and foremost, is a distinct disciplinelfield centrally concerned with practice for the advancement of education

As stated earlier, curriculum studies is not a theoretic field centred on 'understanding curriculum' as conceived by Pinar and his collaborators. It is, in the words of Connelly and Xu (2012), a 'practical' field 'with actions of making and doing as ends' (p. 117). As such, curriculum studies needs to be regarded as a distinctive field of practice in its own right, with its own topics and preoccupations and its own unique ways of theorising (to be introduced next). This is in contrast to the contemporary curriculum field in which topics, preoccupations, and forms of theorising are largely generated through disciplines like humanities, arts, and related discourses. The field is also theoretical in the sense that it brings to bear on the study and theorising of practice a broad range of theories from various sources - psychological, sociological, historical, philosophical, and so forth - both classical and contemporary. These two claims find support in the European history of educational thinking in which Didaktik has long been held as a distinctive discipline in its own right. It is a discipline that is centrally concerned with the work and practice of schooling (Hopmann \& Gundem, 1998), in which the role of theories derived from external sources is only of 'a serving and subordinate nature' (Künzli, 2013).

Furthermore, the field of curriculum needs to concern itself with the advancement of education. As such, curriculum studies is a normative undertaking which needs to be animated and informed by a vision of what education should be. Further, it need to be concerned with how that vision is translated into curriculum development and into classroom practice. Schwab's 'practical' series is informed by a vision of liberal education centred on an image of an educated person who possesses an understanding of culture and the world and a set of powers that enables 
him or her to face the challenges in the society of his times. The cultivation of that set of powers is achieved through interactions with the essence of curriculum content, enabled by a liberal curriculum that promotes conversations, discourses, and practical inquiry through a 'learning community' (Deng, 2018a; Reid, 1984). Likewise, Bildung-centred Didaktik (the primary school of German Didaktik) is directed to a vision of education in terms of Bildung - referring to the self-formation, encompassing the cultivation of human powers, self-awareness, liberty and freedom, responsibility and dignity, self-determination, (autonomy), co-determination (participation) and solidarity (von Humboldt, 2000; Klafki, 1998). The formation and cultivation is achieved through encounters with the 'educational substance' of content embodied in the state curriculum framework, necessitated by the teacher who unlocks the educational potential of content for Bildung (Deng, 2018a).

To invoke Schwab's model of liberal education and Bildung-centred Didaktik is to call attention to a kind of curriculum questions - concerning educational aim, content, and methods that is highly relevant for the advancement of education in the twenty-first century. Both models provide a viable alternative to the OECD's discourse on twenty-first century competencies concerning the development of higher-order thinking such as critical thinking, innovation creativity and imagination deemed important for the knowledge society (see Deng, 2018a). Elsewhere, I have argued that if education is centrally concerned with the development of human powers (capacities or abilities, ways of thinking, understanding worlds) in the twenty-first century, we need to grapple with questions such as:

What does it mean to be an active individual - an intellectual and moral agent - who is actively participating in and interacting with the current social, cultural and physical world characterised by globalisation, rapid technological advancement, an ever- 
increasing rate of information exchange, and mobility? What are the intellectual, moral, social, civic, aesthetic, technological and (even) physical powers such an educated person needs to possess? ... In addition to academic, disciplinary knowledge, what are the other forms of knowledge that could contribute to the cultivation of human powers for all students? How would all these knowledge forms be conceived or re-conceived in ways that are productive of the cultivation? ...How would various kinds of knowledge be selected, translated and organised into the content of the curriculum geared towards cultivating human powers for all students? How would content be analysed and unpacked in ways that open up manifold opportunities for self-formation and the cultivation of human powers? (Deng, 2018a, pp. 346-347).

Questions as such call for a visionary and innovative curriculum thinking and theorising grounded in the social, cultural, and institutional realities of schooling.

However, as noted earlier, the advancement of education through schooling has been lost sight of in contemporary curriculum theory and discourse. The concern for cultivating human powers, and related questions about knowledge and content, seem be hollowed out as the notion of power is often conflated with the connotation of dominating, oppressing, controlling, or disciplining, particularly within the frameworks of Marxist and postmodern curriculum theory. What knowledge is of most worth and what constitutes curriculum content are often substituted or replaced by the political question of whose knowledge is of most worth.

Practice and inner work of schooling as a complex institution provides the essential starting point and subject matter for theorising 
From a Schwabian perspective, curriculum theory and theorising must be concerned with practice and the inner work of schooling which are defined by specific curriculum content or material, specific students, and specific teachers within a specific instructional context. As Schwab (2013/1970) state,

[C]urriculum is brought to bear, not on ideal or abstract representations, but on the real thing, on the concrete case, in all its completeness and with all its differences from all other concrete cases, on a large body of fact concerning which the theoretic abstraction is silent. The materials of a concrete curriculum will not consist merely of portions of 'science', of 'literature' and of 'process'. On the contrary, their constituents will be particular assertions about selected matters couched in a particular vocabulary, syntax and rhetoric. There will be perceptions conditioned by particular past conditionings of particular things and events. The curriculum constituted of these particulars will be brought to bear, not in some archetypical classroom, but in a particular locus in time and space with smells, shadows, seats and conditions outside its walls, which may have much to do with what is achieved inside. Above all, the supposed beneficiary is not the generic child, not even a class or kind of child out of the psychological or sociological literature pertaining to the child. The beneficiary will consist of very local kinds of children and, within the local kinds, individual children. The same diversity holds with respect to teachers and what they do. (p. 611)

Curriculum practice thus entails deliberative decision-making that addresses specific issues and problems arising from a need or a desire for improvement - concerning curriculum content, students and the teacher - within a specific context of a school or classroom. And, deliberative decision-making requires the use of theory to illumine and interpret those specific issues and 
problems. In other words, practice is not a technological and rationalistic undertaking directed towards predetermined outcomes and objectives - as construed by curriculum re-conceptualists when attacking traditional curriculum theory.

This 'practical' conception of practice calls for what Connelly and Xu (2010) called $a$ practice-context-theory nexus in curriculum theorising, if theory is to be relevant to practice. In this approach issues and problems concerning practice are to be taken as the starting point for curriculum inquiry and theory development. Practice is viewed as situated or embedded in the social and cultural context of schooling which, in turn, provides an important 'interpretive frame' for understanding issues and solutions. Furthermore, theory is drawn upon from external sources to help account for the practice in question, and thus assist in generating new theory. Such an approach to curriculum theorising is largely compatible with the one in the German Didaktik tradition. '(T)he only legitimate approach to theory building', according to Gundem (2000), 'is to examine the educational phenomena as they exist in the practice of teaching and schooling' ( $\mathrm{p}$. 241). And, practice is viewed as embedded in context where practice occurs - past, present and future (Gundem, 2000). Furthermore, theoretical perspectives and insights - particularly derived from philosophy and history - are employed for theoretical formations of practice (Schriewer, 2017).

This way of theorising is evident in 'External reform initiatives and teachers' efforts to reconstruct their practice' (Spillane, 1999). In the article James Spillane investigated how 'teachers' capacity and will to reconstruct their mathematics practice' interplayed with 'incentives and opportunities for teachers to learn about practice'. This issue was seen as not only situated in a particular school district but also embedded in the context of national, state and local instructional reforms in the US. The investigation was informed by theoretical perspectives 
from literatures on educational policy and reform, mathematics education, teacher learning and professional development. Based on extensive sets of data collected through teachers' survey, classroom observations, and teachers' interviews across nine school districts, Spillane developed a model of teachers' zones of enactment - the space in which teachers make sense of and enact reform ideas - that can account for teachers' response to mathematics reforms. The model, while foregrounding teachers as active agents, reveals external a set of factors - in terms of organizations, associations and individuals, and the opportunities and incentives - that can influence the classroom enactment of reform initiatives.

This approach, then, leads to the establishment of a model or a set of theoretical propositions concerning practice that can inform policy making, professional development, and school improvement. Other theorising works in JCS that reflect an attention to the practicecontext-theory nexus include, for example, Bokhorst-Heng (2007), Goodyear, Casey and Kirk (2017), and Zhang and Heydon (2015). Based on their experience of editing the Sage Handbook of Curriculum and Instruction, Connelly and $\mathrm{Xu}$ (2010) identified a vast body of in-between literature in which 'practice and theory are brought into dialectical relationships in contextual frames' (p. 327). That body of literature, reflecting the embrace of the practice-context-theory nexus vis-a-vis curriculum theorising, is produced by people who are not primarily known as curriculum scholars. As such, it has been ignored by mainstream contemporary curriculum theorists as the literature does not fit with what they believe about curriculum theorising. Another way of theorising sees practice as part of the inner work of schooling as a complex institution nested in social and cultural milieus. Through an empirical unpacking of the inner work of a school as an institution, curriculum scholars provide a set of theoretical categories for understanding the cultural, organizational, and institutional issues surrounding 
practice. In 'Building Potemkin schools: Science curriculum reform in a STEM school', Tang Wei Teo investigated the attempts of Donald, an experienced American chemistry teacher, to implement an inquiry-based science curriculum held as 'highly plausible, rational' and ' beneficial for his students' (Teo, 2012, p. 663). Using the metaphor of 'the Potemkin school', she showed how the school as a formal institution created 'illusory images of the missions, visions, goals, and achievements' for banding purposes and impressing outsiders (p. 673). She revealed further how the inner work of the school was characterized by 'a world of conflicting ideas and actions', 'layers of ideologies', 'diverse expectations', and 'the multiple kinds of facades created by various stakeholders' (p. 672). This set of categories, we believe, can be used to explain the complexity and issues of teacher's enactment of a reformed curriculum in other schools, with the potential of informing deliberative thought and action in school curriculum practice. Other $J C S$ articles that unpack and theorise the inner work of the institution of schooling can be found in the anthology, Rethinking schooling: Twenty-five years of the Journal of Curriculum Studies (2006), edited by Ian Westbury and Geoffrey Milburn.

This approach can be extended beyond the context of an individual school to a national or state school system consisting of a vast number of schools of different types and levels, coordinated and directed by a central agency like the Ministry or Department of Education. Such a system involves complicated 'quasi-practical' issues (Schwab, 1970/2013), calling for quasitheorising that takes account of multi-faceted, interrelated curricular phenomena. Such theorising can be illustrated by the attempts of curriculum scholars to develop a curriculum-making framework that captures the complexity and multi-dimensional nature of curriculum practice in a national or state school system. Based on extensive, large-scale empirical studies of curriculum decision making at all levels of the educational system in the US, Goodlad and associates (1979) 
postulated that curriculum is 'made' in different locales or places: in state departments of education, in local school boards, in schools, and in classrooms. On the basis of this postulation, Doyle articulated a meta-framework of curriculum making that stipulates three interrelated arenas of curriculum making:

- The policy curriculum ('the abstract or ideal curriculum, which defines the connection between schooling and society').

- The programmatic curriculum ('the analytic or formal curriculum, which translates curriculum policy into instruments that are used in actual curriculum events').

- The classroom curriculum ('curriculum events' jointly developed a teacher and students to achieve instructional goals) (Doyle, 1992a, 1992b).

These three domains of curriculum, which are interrelated and inter-dependent (Deng, 2010), are also further articulated by Westbury $(2003,2008)$ and Deng $(2009,2017)$.

With such a framework, curriculum scholars theorised about teaching as a curriculum process (Doyle, 1992a; also see Deng, 2017), state-based curriculum making (Westbury, 2008), curriculum content (Deng, 2009), and pedagogical content knowledge (Deng, 2018b). Their works, together, show the practice and inner work of schooling need to be 'comprehensively framed by... a view of the larger social and educational system in which classrooms were nested' (Westbury, 2008).

It is worth noting that quasi-theorising is also evident in the works of Spillane and his colleagues. Based on large-scale quantitative and qualitative empirical studies that unpacked the inner work of schooling in the US, Spillane and his colleagues developed theoretical explanations and models of the works of teachers and school leaders within particular organisational and institutional milieus (Spillane, Halverson, \& Diamond, 2004; Spillane \& 
Hunt, 2010; Spillane \& Hopkins, 2013). His latest work involves developing theoretical perspectives and research methods that serve to open up the inner work of schooling and its complex relationship with the macro-structures of schooling, with the intention to develop theories and models that are useful to practitioners (I. Westbury, personal communication, September 3, 2018).

In short, another approach to curriculum theorising involves developing theoretical explanations of the inner work of the schooling as a complex institution that can inform the thought and actions of school practitioners. However, this approach, like the one discussed above, would not be considered curriculum theorising by curriculum re-conceptualists as it does not fall within the framework of the reconceptualised field.

Curriculum theorising requires the use of theories in an eclectic, critical, and creative manner

The third proposition concerns eclecticism in relation to curriculum theory development. Since practice and the inner work of schooling are seen as embedded in a broad social, cultural and institutional context, curriculum theorising needs to deal with social, political, cultural, and educational issues concerning the complex interplay between practice and the inner work of schooling on one hand, and society and culture on the other. Therefore, there is a need to eclectically bring to bear theoretical perspectives, theories and models - traditional, contemporary, and critical - from social sciences, humanities, and related discourses that can shed light on such issues and contribute to curriculum theory development. In fact, eclecticism has long been an essential method in the European tradition of educational thinking (Alexander, 
2008) and is 'indispensable' to the development of Didaktik theory in Germany and Germanspeaking countries (Zierer, 2011).

In this connection, the eclectic arts articulated by Schwab are particularly important because they help curriculum theorists to 'ready theory for practical use' (Schwab 1978, p. 323). As mentioned earlier, all theory is incomplete and partial and has a perspective bias. Through the eclectic arts, curriculum scholars 'discover and take practical account of the distortions and limited perspective which a theory imposes on its subject' (p. 323), and modify that theory for practical considerations. They then combine various theories to form a more appropriate 'whole' for application to issues and problems concerning practice and the inner work of schooling. In other words, they are to use various theories in combination 'without paying the full prices of their incompleteness and partiality' (Schwab, 1970/2013, p. 600).

This extremely brief treatment is far from sufficient in capturing the complexity of eclecticism in Schwab's 'practical' series with respect to curriculum theorising. The limited space at my disposal prevents me from providing a discussion of the eclectic arts that are instrumental for readying theory for practical use and relating theory to practice in a complementary and creative manner. Interested readers are urged to consult Schwab's (1971) 'The practical: Arts of eclectic'. This proposition - and the other two as well - must be left for further discussion on other occasions. These three propositions, after all, pose three kinds of challenge for reviving curriculum theorising that matters in practice and in the world of schooling, to which I shall return in what follows.

\section{Conclusion and discussion}


Using the medical framework in Schwab's the Practical 1 paper, I have analysed and diagnosed the current state of contemporary curriculum theorising as a result of the curriculum reconceptualist movement. I argue that curriculum theorising is in serious crisis due to the loss of the original subject of curriculum studies (i.e., practice and the inner work of schooling as an institution). It is also because the task of theorising has been mistakenly construed as the pursuit of 'complicated' understanding, together with an uncritical embrace of postmodernism and related discourses. I propose a way forward to overcome the crisis and to revive curriculum theorising in terms of three propositions. Curriculum studies is not a theoretic enterprise but a practical undertaking centrally concerned with practice for the advancement of education. The starting point and subject of curriculum theorising, therefore, should not be derived from external theoretical discourses - such as existentialism, Marxism or Neo-Marxism, and post-modernism but are to be found in practice and the inner work of schooling as a complex institution. Furthermore, curriculum theorising requires an employment of a variety of theories and models from other disciplines or fields in an eclectic, critical, and innovative manner, rather than a reliance on singular theories or doctrines.

These three propositions are articulated based on Schwab's the Practical - together with his model of liberal education - and informed by Bildung-centered Didaktik. Among many American curriculum theories and schools of thought, the Practical is selected because it represents the kernel of American curriculum studies. It is rooted in and developed out of the rich tradition of curriculum and educational thinking - represented by Dewey, McKeon, Schwab, and Tyler, among others - within the University of Chicago, arguably the birthplace of American curriculum studies. The Practical is, in fact, a transformation and re-invention of traditional curriculum theory by relocating it within the interpretive, hermeneutic, and humanistically- 
oriented realm of human thinking, and by 'fully marrying it with the disciplinary tradition' (Westbury, 2013, Westbury \& Wilkof, 1978). The Practical, Eisner (1984) argued, holds 'the greatest promise for the improvement of those decisions that those who plan school programmes must make' (p. 192). Furthermore, Schwab's model of liberal education, which lies behind his 'practical' series, continues to hold promise of preparing students for life and work in the twentyfirst century (see Deng, 2018a).

Likewise, Bildung-centered Didaktik is chosen among multiple schools or models of German Didaktik ${ }^{8}$ because it stands for the kernel or core of German Didaktik. It is 'the main tradition of didactics and has had the longest and most profound impact' (Gundem, 2000, p. 242). It is positioned within and the realm of human sciences (Geisteswissenschaften) - rather than natural science (Naturwissenschaften) - with strong hermeneutic and interpretative inclination. As such, it is inextricably connected with the rich tradition of European education and Didaktik thinking associated with Kant, Schleiermacher, Humboldt, Comenius, Herbart, Dilthey, Nohl, Weniger, and Klafki, among many others. Furthermore, Bildung-centred Didaktik, as mentioned earlier, provides a viable alternative to the OECD's discourse on twenty-first competencies (for a further discussion, see Willbergh, 2015).

To invoke the Practical and Bildung-centred Didaktik, then, is to seek to (re)connect curriculum studies to the rich traditions of American curriculum and educational thinking and of European Didaktik and educational thinking. These traditions are much needed as they provide us with necessary philosophical and theoretical foundations upon which to reconstruct the curriculum field and develop new curriculum theories that can contribute to practice and the advancement of education in our times. Furthermore, they provide antidotes to the uncritical

\footnotetext{
${ }^{8}$ Other Didaktik schools are, for example, Berliner Didaktik, psychological Didaktik, experimental Didaktik, and dialectical Didaktik (Meyer, 2013; also see Arnold and Lindner-Müller, 2012).
} 
'borrowing' of postmodernism, post-structuralism, and post-humanism from contemporary humanities and social sciences. These traditions, in the words of David Bloom, provide 'a counterpoise to and a repair from the merely current' and a 'resource against the ephemeral' (Bloom, 1987).

My approach to the American curriculum studies and German Didaktik finds support and inspiration in Tradition as challenge by German philosopher Josef Pieper. To correctly understand the tradition that underlies a particular field, he argued, we must distinguish the 'kernel' from the 'periphery'. Furthermore, we need to understand how particular moral and philosophical commitments embodied in the tradition are restated amidst changing conditions (Pieper, 2014).

If we see the three propositions presented above as the "moral and philosophical commitments' embodied in American curriculum studies and German Didaktik, then we must take the challenges of restating these propositions in the current historical moment. There are challenges of (re)establishing curriculum studies as distinctive discipline of practice for the advancement of education in the current changing social, cultural and physical world. There are too challenges of understanding more fully the complexity of practice and the inner work of schooling as a complex institution based upon or informed by extensive, solid empirical research. Furthermore, there are challenges of modifying theory for practical considerations and relating theory to practice in an eclectic, creative, and innovative manner, for the purpose of constructing theory that matters in practice and in the inner work of schooling. These three kinds of challenge are very much interrelated, together testifying that there is indeed a lot - rather than just 'something' - 'for curriculum professors to do' (Schwab, 1983)!

\section{Acknowledgements}


The author would like to express sincere gratitude to Ian Westbury for his useful comments on the earlier versions of this article, and is also grateful for the meaningful comments of two anonymous reviewers.

\section{Disclosure statement}

No potential conflict of interest was reported by the author.

\section{Bio-note}

Zongyi Deng is an associate professor at National Institute of Education, Nanyang Technological University, Singapore. He is also an executive editor of Journal of Curriculum Studies (JCS). His interest areas include curriculum content or subject matter, curriculum theory, didactics (Didaktik), Chinese education, and comparative and international education. His publications appear in JCS, Curriculum Inquiry, Comparative Education, Teaching and Teacher Education, Cambridge Journal of Education, Science Education and other international journals.

\section{References}

Alexander, R. (2008). Pedagogy, curriculum and culture. In K. Hall, P. Murphy, \& J. Soler (Eds.), Pedagogy and practice: culture and identities (pp. 3-27) Thousand Oakes, CA: Sage

Apple, M. W. (1990). The politics of official knowledge in the United States, Journal of Curriculum Studies, 22(4), 377-400.

Apple, M. W. (2004). Ideology and curriculum (3 $3^{\text {rd }}$ ed.). New York, NY: RoutledgeFalmer.

Arnold, K.-H., \& Lindner-Müller, C. (2012). The German tradition in general didactics. Jahrbuch für Allgemeine Didaktik (JfAD - Yearbook for General Didactics), 2, 46-64.

Bokhorst-Heng, W. D. (2007). Multiculturalism's narratives in Singapore and Canada: Exploring a model for comparative multiculturalism and multicultural education. Journal of Curriculum Studies, 39(6), 629-658.

Bloom, A. (1987). The closing of the American mind. New York, NY: Simon and Schuster. 
Carlson, D. (1987). Teachers as political actors: From reproductive theory to the crisis of schooling. Harvard Educational Review, 57(3), 283-308.

Christou, T., \& DeLuca, C. (2013). Curriculum studies at a crossroad: Curating inclusive and coherent curriculum conversations in Canada. Journal of the Canadian Association for Curriculum Studies, 11(1), 13-22.

Connelly, M. F. (2010). Notes for an AERA talk that wasn't: Observations and a proposal. Paper presented at the meeting of American Educational Research Association, April 30-May 4 Denver, CO.

Connelly, M. F. (2013). Joseph Schwab, curriculum, curriculum studies and educational reform. Journal of Curriculum Studies, 45(5), 622-639.

Connelly, F. M., \& Xu, S. (2008). The landscape of curriculum and instruction: Diversity and continuity. In F. M.Connelly, M. F.He, \& J.Phillion (Eds.), The SAGE handbook of curriculum and instruction (pp. 514-533). Thousand Oaks, CA: Sage.

Connelly, F. M., \& Xu, S. (2010). An overview of research in curriculum inquiry. In P. Peterson, E. Baker, \& B. McGaw (Eds.), International encyclopedia of education (3rd ed., pp. 324-334). Oxford, UK: Elsevier

Connelly, F. M., \& Xu, S. (2012). Curriculum and curriculum studies. In J. Arthur \& A. Peterson (Eds.), The Routledge companion to education (pp. 115-124). New York, NY: Routledge.

De Alba, A. (2000). Curriculum in the postmodern condition. New York, NY: Peter Lang.

Deng, Z. (2009). The formation of a school subject and the nature of curriculum content: An analysis of liberal studies in Hong Kong. Journal of Curriculum Studies, 41(5), 585-604.

Deng, Z. (2010). Curriculum planning and systems change. In B. McGaw, E. Baker, \& P. Peterson (Eds.), International Encyclopaedia of Education (3rd ed.) (pp. 384-389). Oxford, UK: Elsevier.

Deng, Z. (2013). The Practical, curriculum, theory and practice: an international dialogue on Schwab's the 'Practical 1'. Journal of Curriculum Studies, 45(5), 583-590.

Deng, Z. (2017). Rethinking curriculum and teaching. In G. W. Noblit (Ed.), Oxford research encyclopaedia of education. New York, NY: Oxford University Press.

Deng, Z. (2018a). Bringing knowledge back in: perspectives from liberal education. Cambridge Journal of Education, 48(3), 335-351.

Deng, Z. (2018b). Pedagogical content knowledge reconceived: Bringing curriculum thinking into the conversation on teachers' content knowledge. Teaching and Teacher Education, 72, 155-164. 
Doll Jr, W. E. (1989). Foundations for a post-modern curriculum. Journal of Curriculum Studies, 21(3), 243-253.

Doyle, W. (1992a). Constructing curriculum in the classroom. In F. K. Oser, A. Dick, \& J. Patry (Eds.), Effective and responsible teaching: The new syntheses (pp. 66-79). San Francisco, CA: Jossey-Bass.

Doyle, W. (1992b). Curriculum and pedagogy. In P. W. Jackson (Ed.), Handbook of research on curriculum (pp. 486-516). New York, NY: Macmillan.

Eisner, E. (1984). No easy answers: Joseph Schwab's contributions to curriculum. Curriculum Inquiry 14(2), 201-210.

Giroux, H. (1988). Liberal arts, teaching, and critical literacy: Toward a definition of schooling as a form of cultural politics. In W.F. Pinar (Ed.), Contemporary curriculum discourses (pp. 243263). Scottsdale, AZ: Gorsuch Scarisbrick.

Giroux, H. A., McLaren, P. L. (Eds.). (1989). Critical pedagogy, the state, and cultural struggle. Albany, NY: State University of New York Press.

Goodlad, J. I. (1984). A place called school. Prospects for the future. New York, NY: McGrawHill

Goodlad, J. I., \& Associates. (1979). Curriculum inquiry: The study of curriculum practice. New York, NY: McGraw-Hill.

Goodyear, V. A., Casey, A., \& Kirk, D. (2017). Practice architectures and sustainable curriculum renewal. Journal of Curriculum Studies, 49(2), 235-254.

Graham, R. J. (1992). Currere and reconceptualism: the progress of the pilgrimage 1975-1990. Journal of Curriculum Studies, 24(1), 27-42.

Grumet, M. R. (1976a). Existential and phenomenological foundations. In W. F. Pinar \& M. R. Grumet (Eds.), Toward a poor curriculum (pp. 31-50). Dubuque, IA: Kendall Hunt.

Grumet, M. R. (1976b) Psychoanalytic foundations. In W. F. Pinar \& M. R. Grumet (Eds.), Toward a poor curriculum (pp. 111-146). Dubuque, IA: Kendall Hunt.

Gundem, B. B. (2000). Understanding European Didactics. In B. Moon, M. Ben-Peretz and S. Brown (eds), Routledge international companion to education (pp. 235-62). London, UK: Routledge.

Hicks, S. R. (2004). Explaining postmodernism: Skepticism and socialism from Rousseau to Foucault. Tempe, AZ: Scholargy Publishing. 
Hlebowitsh, P. S. (1992). Amid behavioural and behaviouristic objectives: reappraising appraisals of the Tyler Rationale. Journal of Curriculum Studies, 24(6), 533-547.

Hlebowitsh, P. S. (1995). Interpretations of the Tyler Rationale: A reply to Kliebard. Journal of Curriculum Studies, 27(1), 89-94.

Hopmann, S., \& Riquarts, K. (1995). Starting a dialogue: Issues in a beginning conversation between Didaktik and the curriculum traditions. Journal of Curriculum Studies, 27(1), 3-12.

Hopmann, S., \& Gundem, B. B. (1998). Didaktik meets curriculum. In B. B. Gundem and S. Hopmann (eds), Didaktik and/or Curriculum: An International Dialogue (pp. 331-350). New York, NY: Peter Lang.

Humboldt, W. V. (2000). Theory of Bildung. In I. Westbury, S. Hopmann, \& K. Riquarts (Eds.), Teaching as a reflective practice: The German Didaktik tradition (pp. 57-61). Mahwah, NJ: Erlbaum.

Jackson, P. W. (1992). Conceptions of curriculum and curriculum specialists. In P. W. Jackson (Ed.), Handbook of research on curriculum: A project of the American Educational Research Association (pp. 3-40). New York, NY: Macmillan.

Klafki,W. (1998). Characteristics of critical constructive Didaktik. In B. B. Gundem, \& S. Hopmann (Eds.), Didaktik and/or curriculum: An international dialogue (pp. 307-330). New York, NY: Peter Lang.

Kliebard, H. M. (1970). The Tyler Rationale. School Review, 78(2), 259-272.

Kliebard, H. M. (1986). The struggle for the American curriculum. New York, NY: Routledge.

Kliebard, H. M. (1992). Forging the American curriculum: Essays in curriculum history and theory. New York, NY: Routledge.

Künzli, R. (2013). Memorizing a memory: Schwab's the Practical in a German context. Journal of Curriculum Studies, 45(5), 668-683.

Levine, D. N. (2006). Powers of the mind: The reinvention of liberal learning in America. Chicago, IL: University of Chicago Press.

Malewski, E. (Ed.). (2010). Curriculum studies handbook: The next moment. New York, NY: Routledge.

McLaren, P. (2015). Life in schools: An introduction to critical pedagogy in the foundations of education. New York, NY: Routledge. 
Meyer, H. (2013). Crisis and new orientation of general didactics in Germany. In X. M. Peng (ed.), Sino-German dialogue on didactics: Post graduate academic forum (pp. 16-24). Shanghai, China: East China Normal University.

Peterson, J. B. (2017). Identity politics \& the Marxist lie of white privilege [You Tube video]. Retrieved from https://www.youtube.com/watch? $v=0$ fmuCXRMoSA\&t=1230s

Peterson, J. B. (2018). 12 rules for life: An antidote to chaos. Toronto: CA: Random House Canada.

Pieper, J. (2014). Tradition as challenge: Essays and speeches. South Bend, IN: St. Augustine's Press.

Pinar, W. (Ed.). (1975). Curriculum theorizing: The reconceptualists. Troy, NY: McCutchan Publishing Corporation.

Pinar, W. F. (1978). The reconceptualisation of curriculum studies. Journal of Curriculum Studies, 10(3), 205-214.

Pinar, W. F. (1992). 'Dreamt into existence by others': curriculum theory and school reform. Theory Into Practice, 31(3), 228-235.

Pinar, W. F. (2003). (Ed.). International handbook of curriculum research. Mahwah, NJ: Lawrence Erlbaum.

Pinar, W. F (2004). What is curriculum theory? Mahway. NJ: Lawrence Erlbaum

Pinar, W. F. (2008). Curriculum theory since 1950: Crisis, reconceptualization, internationalization. In F. M.Connelly, M. F.He, \& J.Phillion (Eds.), The SAGE handbook of curriculum and instruction (pp. 491-513). Thousand Oaks, CA: Sage.

Pinar, W. F., Reynolds, W. M., Slattery, P., \& Taubaum, P. M. (1995). Understanding curriculum: An introduction to the study of historical and contemporary curriculum discourses. New York, NY: Peter Lang.

Popkewitz, T. S. (2009). Curriculum study, curriculum history, and curriculum theory: the reason of reason. Journal of Curriculum studies, 41(3), 301-319.

Reid, W. A. (1984). Curriculum, community, and liberal education: A response to the Practical 4. Curriculum Inquiry, 14(1), 103-111.

Reid, W. A. (2001). Rethinking Schwab: Curriculum theorizing as a visionary activity. Journal of curriculum and supervision, 17(1), 29-41. 
Ruzgar, M. E. (2018). On matters that matter in the curriculum studies: An interview with Ian Westbury. Journal of Curriculum Studies, 50 (6), xxx-xxx.

Schriewer, J. (2017). Between the philosophy of self-cultivation and empirical research: Educational studies in Germany. In G. Whitty \& J. Furlong (Eds.), Knowledge and the study of education: An international exploration (pp. 75-99). Oxford, UK: Symposium Books.

Schubert, W. H. (2009). Currere and disciplinarity in curriculum studies: Possibilities for education research. Educational Researcher, 38(2), 136-140.

Schubert, W. H., Willis, G. H., \& Short, E. C. (1984). Curriculum theorizing: An emergent form of curriculum studies in the United States. Curriculum Perspectives, 4(1), 69-74.

Schwab, J. J. (1969). College curriculum and student protest. Chicago, IL: University of Chicago Press.

Schwab, J. J. (2013). The practical: a language for curriculum. Journal of Curriculum Studies, 45(5), 591-621. (Reprinted from The practical: a language for curriculum by J. J. Schwab, 1970, Washington, D.C: National Education Association)

Schwab, J. J. (1971). The practical 2: arts of eclectic. School Review, 79(4), 493-542.

Schwab, J. J. (1973). The practical 3: translation into curriculum. School Review, 81(4), 501522.

Schwab, J.J. (1983) The practical 4: Something for curriculum professors to do. Curriculum Inquiry, 13 (3), 239-265.

Slattery, P. (1995). Curriculum development in the postmodern era. New York, NY: Garland.

Sokal, A., \& Bricmont, J. (1998). Intellectual impostures. London, UK: Profile Books.

Spillane, J. P. (1999). External reform initiatives and teachers' efforts to reconstruct their practice: The mediating role of teachers' zones of enactment. Journal of curriculum Studies, $31(2), 143-175$.

Spillane, J. P., Halverson, R., \& Diamond, J. B. (2004). Towards a theory of leadership practice: A distributed perspective. Journal of curriculum studies, 36(1), 3-34.

Spillane, J. P., \& Hunt, B. R. (2010). Days of their lives: a mixed-methods, descriptive analysis of the men and women at work in the principal's office. Journal of curriculum studies, 42(3), 293-331.

Spillane, J. P., \& Hopkins, M. (2013). Organizing for instruction in education systems and school organizations: How the subject matters. Journal of Curriculum Studies, 45(6), 721-747. 
Teo, T. W. (2012). Building Potemkin schools: Science curriculum reform in a STEM school. Journal of Curriculum Studies, 44(5), 659-678.

Tyler, R. W. (1949). Basic principles of curriculum and instruction. Chicago, IL: University of Chicago Press.

Trueit, D., Wang, H., Doll, W. \& Pinar, W. F. (Eds.) (2003). The internationalization of curriculum studies. New York, NY: Peter Lang.

Westbury, I. (2000). Teaching as a reflective practice: What might Didaktik teach curriculum. In I. Westbury, S. Hopmann, \& K. Riquarts (Eds.), Teaching as a reflective practice: The German Didaktik tradition (pp. 15-39). Mahwah, NJ: Erlbaum.

Westbury, I. (2005). Reconsidering Schwab's “practicals": A response to Peter Hlebowitsh's "Generational ideas in curriculum: A historical triangulation." Curriculum Inquiry, 35(1), 89101.

Westbury, I. (2007). Theory and theorizing in curriculum studies. In E. Forsberg (ed.), Curriculum Theory Revisited, Studies in Educational Policy and Educational Philosophy, Research Reports 7 (pp. 1-19). Uppsala, Sweden: Uppsala University.

Westbury, I. (2008). The making of formal curricula: Why do states make curricula, and how? In F. M. Connelly, M. F. He, \& J. Phillion (Eds.), The Sage handbook of curriculum and instruction (pp. 45-65). Thousand Oaks, CA: Sage.

Westbury, I. (2013) .Reading Schwab's 'Practical' as an invitation to enquiry. Journal of Curriculum Studies, 45 (5), 640-651.

Westbury, I., \& Milburn, G. (Eds.). (2006). Rethinking schooling: Twenty-five years of the journal of curriculum studies. New York, NY: Routledge.

Westbury, I., \& Wilkof, N. J. (1978). Introduction. In I. Westbury \& N. J. Wilkof (Eds.), Science, curriculum, and liberal education: Selective essays (pp. 1-40). Chicago, IL: The University of Chicago Press.

Wraga, W., \& Hlebowitsh, P. (2003). Toward a renaissance in curriculum theory and development in the USA. Journal of Curriculum Studies, 35(4), 425-437.

Zhang, Z., \& Heydon, R. (2016). The changing landscape of literacy curriculum in a SinoCanada transnational education programme: An actor-network theory informed case study. Journal of Curriculum Studies, 48(4), 547-564.

Zierer, K. (2011). Pedagogical eclecticism. Journal of Educational Thought, 45 (1), 3-20. 